\title{
CREDit RATINGS AND THE EVOLUTION OF THE MORTGAGE-BACKED SECURITIES MARKET
}

\author{
By Jie (Jack) He, Jun (QJ) Qian, and Philip E. Strahan ${ }^{\dagger}$
}

December 2010

\begin{abstract}
We compare the structure and performance of private (non-GSE) mortgage-backed securities sold by large issuers vs. those sold by small issuers over the period 2000-2006. Securities sold by large issuers have less subordination - a greater fraction of the deal receiving AAA rating - than those sold by small issuers. Prices for AAA-rated and non-AAA rated tranches sold by large issuers fell more when the market turned down than those sold by small issuers, and this difference was concentrated among tranches issued between 2004 and 2006. These results suggest that rating agencies grant unduly favorable ratings to large issuers, especially during market booming periods.
\end{abstract}

JEL Classifications: G2, G1, L1.

Keywords: Credit ratings, mortgage-backed securities, conflict of interest, tranche, subordination.

\footnotetext{
${ }^{\dagger}$ He: University of Georgia, jiehe@uga.edu; Qian: Boston College, qian@bc.edu; Strahan (corresponding author): Boston College and NBER, strahan@bc.edu. We appreciate helpful comments from Patrick Bolton, Gerard Hoberg, Joel Shapiro, Richard Stanton, Dragon Tang, James Vickery, and seminar/session participants at Boston College, Federal Reserve Bank of New York, Queen's University (Canada), China International Conference in Finance (Beijing), European Finance Association meetings (Frankfurt), the NBER conference on securitization and University of Maryland Conference on Financial Economics. We thank Calvin Chau, Hugh Kirkpatrick, Sailu Li, Yingzhen Li, and Chenying Zhang for excellent research assistance and Boston College and University of Georgia for financial support.
} 
The explosive growth of the private, non-GSE backed mortgage-backed securities (MBS) market lies at the heart of the 2007-2009 Global Financial Crisis. This market both fueled and was fueled by the expansion of subprime credit and the housing boom. We study the role of the three primary rating agencies-Moody’s, S\&P, and Fitch—in the expansion of the MBS market.

Rating agencies play an important role in all fixed income markets, in part because they have access to privileged information on securities and their issuers, a privilege protected from regulations such as Reg-FD. The agencies, however, have received sharp criticism for their ratings practices in the MBS market. Many critics point to a potential conflict in rating agencies’ fees and income structure. Instead of being compensated by the investors who consume their product, issuers pay the rating agencies. The conflict of interest hypothesis thus stipulates that agencies may provide unduly favorable ratings, especially to large issuers who bring, and could potentially take away, substantial revenues.

The risk of lost reputation, and hence lost future profits, potentially offsets the conflict of interest problem. Because this industry has just three dominant players, loss of reputation stemming from ratings mistakes could come with substantial costs. ${ }^{1}$ The balance of forces in the MBS market, however, may have tilted toward ratings ‘inflation,’ particularly for large issuers when this new and rapidly growing market boomed between 2004 and 2006. First, the boom in housing meant that MBS generated a significant new revenue stream for rating agencies. Second, unlike the corporate bond market, a small number of large issuers of MBS brought many deals to the ratings agencies and thus had substantial bargaining power over them. ${ }^{2}$ Theoretical research (e.g., Bolton, Freixas, and Shapiro, 2009; Bar-Isaac and Shapiro, 2010) shows that the perverse incentive of the

\footnotetext{
${ }^{1}$ Becker and Milbourn (forthcoming) provide evidence that increased competition leads ratings agencies to become less conservative, consistent with competition reducing rents and thus reputational costs of rating mistakes.

2 In the case of Moody’s, as the total volume of originations of subprime mortgages rose from $\$ 65$ billion in the late 1990s to over $\$ 600$ billion in 2006, Moody’s profits tripled between 2002 and 2006. In 2006, the peak of the housing and related financial markets, according to their disclosure, 44 percent of Moody's revenues came from rating structured finance products, exceeding the 32 percent of revenues from rating corporate bonds.
} 
rating agencies is strongest during market booms because the benefits from additional rating business generated (net of potential reputational costs) are the highest.

These facts and arguments provide the basis of our empirical study. We start by matching a large sample of MBS tranches sold between 2000 and 2006 with information on the structure, price and rating history (from Moody’s, S\&P and Fitch) to their issuers. Around sixty percent of the tranches are rated AAA (un-weighted), the highest possible grade, by each of the three rating agencies. We then compare tranches sold by large issuers vs. small issuers, where issuer size is based on the issuing institutions' annual market share. We also differentiate market boom years (2004-2006), during which the principal amount issued accounts for a large fraction of the total amount issued over the entire sample period, from the earlier years (2000-2003).

To examine the structure of the MBS tranches, we use the degree of subordination, defined as the fraction of financing within a deal rated AAA. All else equal, an increase in this fraction indicates a greater degree of ratings inflation. This fraction affects issuer profits because less subordination implies more total revenues for the entire deal given the large, global demand for AAA tranches. If large issuers can exert their bargaining power and influence on rating agencies, then securities sold by large issuers, and in particular those issued during the market boom years, would have a larger fraction rated AAA (conditional on the quality of the collateral). Given the tranching and the alleged biased rating process, less subordination would in turn lower the quality conditional on the credit rating. In our second set of tests, we thus examine the ex post performance of the AAA-rated MBS securities by looking at price changes between the origination date and April, 2009. If large issuers received more favorable ratings than small issuers, then we should observe a greater price drop by securities sold by large issuers, again particularly for cohorts issued during market booming years. 
Our paper complements and contributes to the growing literature on the anatomy of the housing crisis and the role of MBS markets in this crisis, as well as incentive problems of financial service industries generally. There are several recent papers (e.g., Ashcraft, Goldsmith-Pinkham, and Vickrey, 2009; Benmelech and Dlugosz, 2009a, 2009b; Griffin and Tang, 2009) that empirically examine credit ratings in the broad structured-finance markets (including MBS). Griffin and Tang (2009) examine possible flaws of rating agencies’ internal models, and Ashcraft et al. (2009) examine the pooling and tranching process of mortgages into MBS. By contrast, our paper is the first to test for incentive problems of rating agencies related to issuer size; and, we take a 'valuation from outside' approach by testing whether and how the market incorporates possible biases in the rating process.

\section{DATA}

We begin the process of data compilation with the Securities Data Corporation (SDC) database, which provides a large sample of tranches of privately-issued (i.e. non-GSE) MBS deals. For each deal, SDC provides the basic information on asset/collateral types (mortgage, credit card, auto loans, bonds, etc), the number of tranches, as well as information on the issuer(s) and bookrunner(s). For other deal and tranche characteristics, including initial and subsequent ratings and prices, principal amount, coupon type and rate, and maturity (weighted average life, and whether the tranche is paid off prior to April 2009), we rely on manually collected data from Bloomberg. Our sample includes more than 85,000 MBS tranches originated and issued between 2000 and 2006.

Table 1 reports the top five issuers in each year of our sample period. We rank institutions in a given year on the number of deals issued that year. We also derive issuer rankings based on the 
dollar amount issued in each year and this alternative procedure yields very similar rankings (not reported).

Table 1 - Top 5 Issuers of Private Mortgage-Backed Securities (2000-2006)

\begin{tabular}{cccccccc}
\hline Rank & 2000 & 2001 & 2002 & 2003 & 2004 & 2005 & 2006 \\
\hline 1 & General Motors & General Motors & General Motors & General Motors & Countrywide & Countrywide & Countrywide \\
2 & Countrywide & Credit Suisse & Countrywide & Countrywide & General Motors & General Motors & General Motors \\
3 & Wells Fargo & Countrywide & WaMu & Lehman & Bear Stearns & Lehman & Bear Stearns \\
4 & JP Morgan & Wells Fargo & Credit Suisse & Credit Suisse & Lehman & Bear Stearns & Lehman \\
5 & Bank of America & Lehman & Lehman & Bear Stearns & Bank of America Bank of America & IndyMac \\
$\begin{array}{l}\text { Market } \\
\text { Share }\end{array}$ & $38 \%$ & $47 \%$ & $45 \%$ & $42 \%$ & $40 \%$ & $41 \%$ & $39 \%$ \\
\hline
\end{tabular}

Notes: This table shows the top 5 issuers of private mortgage-backed securities by the number of deals during 2000-2006 using information from SDC. The last row shows the total market share of the top 5 issuers of a given year based on the number of deals they issue.

The list of top-five issuers changes over time, but most are well-known, large institutions involved in various aspects of housing and subprime lending. Interestingly, each of the top five issuers in 2006, Countrywide, GM (through its finance arm GMAC), Bear Stearns, Lehman Brothers, and IndyMac, failed during the ensuing crisis! The MBS market is highly concentrated among large issuers, with the top five accounting for $38 \%$ to $47 \%$ of all the newly issued securities. The dominance of large issuers implies that they have considerable bargaining power over rating agencies as they can bring and take away tremendous amounts of rating business.

\section{EMPIRICAL TESTS AND RESULTS}

Cash flows and risk are evaluated quite differently in structured finance products compared to the traditional corporate bond market. The cash flows and risks of corporate bonds - and hence 
ratings - are tied to the performance and growth prospects of one company. By contrast, structured finance involves a securitization process with pooling and tranching (possibly multiple times) of a large number of credit-sensitive assets. For a fixed collateral pool (in the case of MBS, these would be home mortgages), structured finance separates the pool into prioritized claims called tranches, which absorb losses from the underlying portfolio following seniority; hence, tranche-level ratings depend both on the risks and diversification of the collateral pool as well as on the structuring of the cash flows. While securitization has revolutionized fixed income markets and brought billions of dollars of revenues to Wall Street, for many investors, even some institutional investors, this process can be opaque and filled with problems of asymmetric information and moral hazard. ${ }^{3}$

In addition, for many institutional investors, especially those focusing on the fixed income markets and seeking high yield/return investment opportunities but constrained by the level of risk exposure (ratings), highly rated MBS tranches offer an ideal investment instrument. As shown in Coval et al. (2009), securitization can produce many more AAA-rated tranches (among the population of all tranches) than the fraction of AAA-rated corporate bonds (only about one percent of all corporate bonds are AAA rated). The pooling and tranching process eliminates most of the idiosyncratic risk of underlying assets, while the remaining systematic risk implies higher expected returns. For regulated banks, broker dealers, and insurance companies, AAA-rated credits are attractive because little regulatory capital needs to be held in reserve. Moreover, seemingly safe structured finance products were used to increase the supply of collateral backing repurchase agreements that many institutional investors used to manage their liquidity risk (Gorton and Metrick, 2010). Hence, securitization helps supply the very strong demand for highly rated assets.

Our main hypothesis is that credit rating agencies (Moody’s, S\&P, and Fitch) favor large

\footnotetext{
${ }^{3}$ See, e.g., Coval et al. (2009) for a review of structured finance, and Ashcraft and Schuermann (2008) for a review of agency problems in securitization. See Keys et al (2009) for evidence that securitization led to moral hazard (lax screening).
} 
issuers because these issuers bring in more rating businesses and revenues. Moreover, the incentive toward favoritism ought to be stronger during market booming periods. More favorable ratings imply a greater fraction of financing in the highly-rated tranches (i.e. the AAA slice), which implies greater risk across all tranches within a deal. Figure 1 plots the median fraction of AAA tranches of MBS, sorted by issuing year and issuer size. The sample includes all MBS deals (about 5,500) whose tranches received ratings from Moody’s, S\&P, or Fitch. “Fraction of AAA Tranches” equals the total principal amount of all the AAA tranches in an MBS deal divided by the total principal amount of all tranches in the deal. " "Big issuer" indicates that the market share falls into the top $10 \%$ of the market share distribution in a given year, while "Small issuer" refers to the other issuers in the same year.

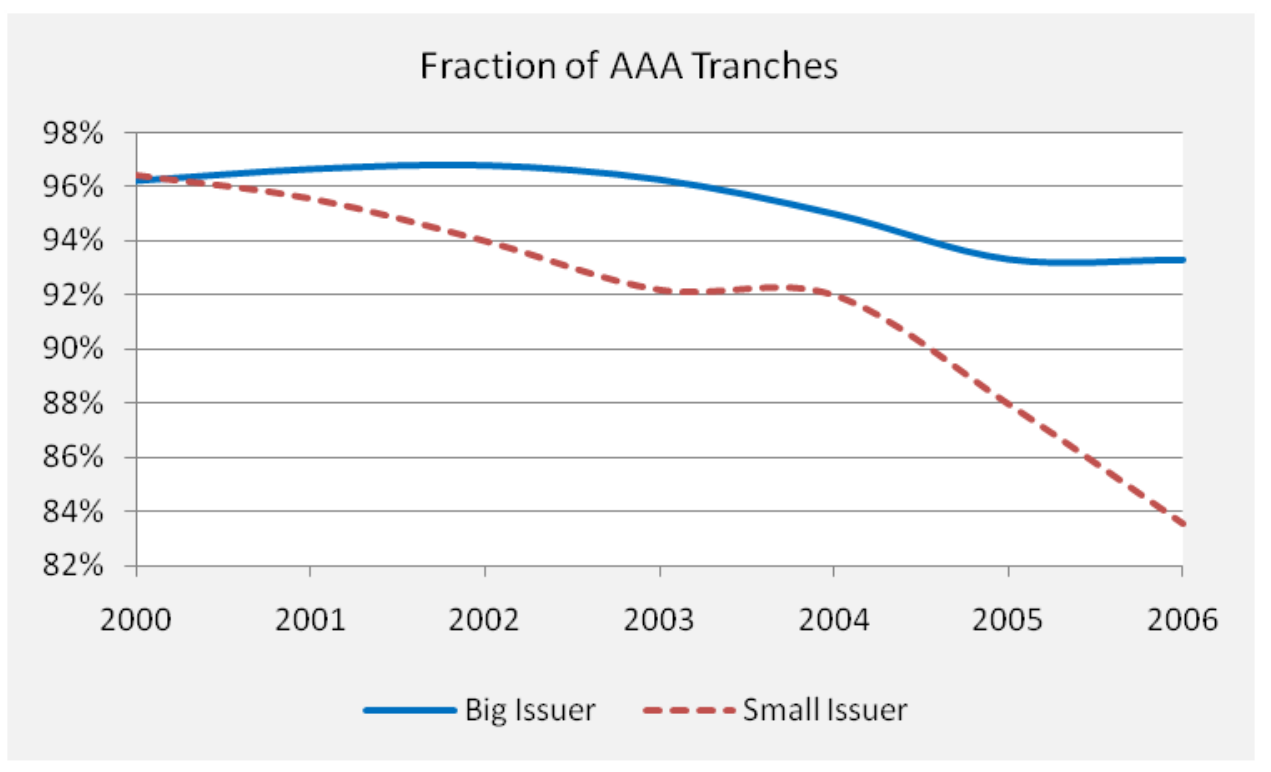

Figure 1: Fraction of Financing in AAA Tranches

This figure shows the median of the fraction of total deal-level financing rated AAA for privately-issued MBS. The sample includes all MBS deals whose tranches received ratings from Moody's, S\&P, or Fitch. "Fraction of AAA Tranches" is the total principal amount of all AAA tranches in an MBS deal, divided by the total principal amount of all tranches in that deal. Issuer market share is calculated as the number of deals originated by the issuer divided by the total number of deals in the current year. "Big issuer" means that the market share of the issuer falls into the top $10 \%$ of the market share distribution in that year, and "Small issuer" refer to the rest of issuers in that year.

\footnotetext{
${ }^{4}$ For tranches with more than one rating (which is most of the sample), we define it has AAA only if all of the ratings are AAA.
} 
A few interesting patterns emerge from Figure 1. The median fraction of financing in AAA tranches sold by large and small issuers is quite similar in 2000 (just above 96\% for the median deal), but then trends downward for both groups of securities as the housing and MBS markets grew. More importantly, we observe a divergence in the degree of subordination between deals sold by large vs. small issuers - deals sold by large issuers have a larger fraction rated AAA than those sold by small issuers. The gap increases over time, peaking at about 10 percentage points in 2006, the height of the boom. The patterns in Figure 1 could occur if small issuers moved more aggressively over time into the riskiest segments of the sub-prime mortgage markets. This possibility seems inconsistent with Table 1, however, which shows that the five largest issuers in 2006 all failed. Moreover, He, Qian and Strahan (2010) find similar patterns to those in Figure 1, controlling for observable dimensions of collateral risk and diversification. Hence, Figure 1 suggests that large issuers received more favorable ratings from the agencies, and that this effect grew stronger as the market boomed.

If large-issuer deals really receive inflated ratings - if there is not sufficient subordination then AAA-rated tranches ought to perform worse when the market crashes. To test this notion, we compare the ex-post performance of AAA-rated tranches sold by large vs. small issuers. Our measure of ex post performance equals the cumulative percent change (drop in this case) in the price between the issuance date and April, 2009 (or its payoff date). About 45\% of the tranches that we have information on pricing history are paid off early and before the crisis. ${ }^{5}$

As in Figure 1, we sort data into two groups based on issuer size and we also separate the data into two sets of cohorts: 2000-2003 (non-boom) vs. 2004-2006 (boom). From Panel A, prices

\footnotetext{
${ }^{5}$ Comparing the subsample of tranches with pricing information with the whole sample, we can see that large tranches (principal amount) are more likely to have price information from Bloomberg, which reports prices as the mid-quote (bid-ask) from security dealers. Once a tranche is paid off, all the ratings are withdrawn and the reported price series stop. Note that these MBS securities do not experience bankruptcy when the underlying assets become distressed due to the special legal status of the 'Special Purpose Vehicles." Instead, actual and expected future cash flows fall, leading to a decline in the price.
} 
remain more or less flat during the first few years after issuance, but begin to drop early in 2007. From Panel B, prices of tranches issued during the market boom and by large issuers drop more during 2007-2009 than those issued by small issuers. As of April 2009, prices of tranches sold by large issuers drop by 15 percentage points more than those sold by small issuers. These results suggest that, conditional on the rating, tranches sold by large issuers perform worse than those sold by small issuers, especially during the market boom period. ${ }^{6}$

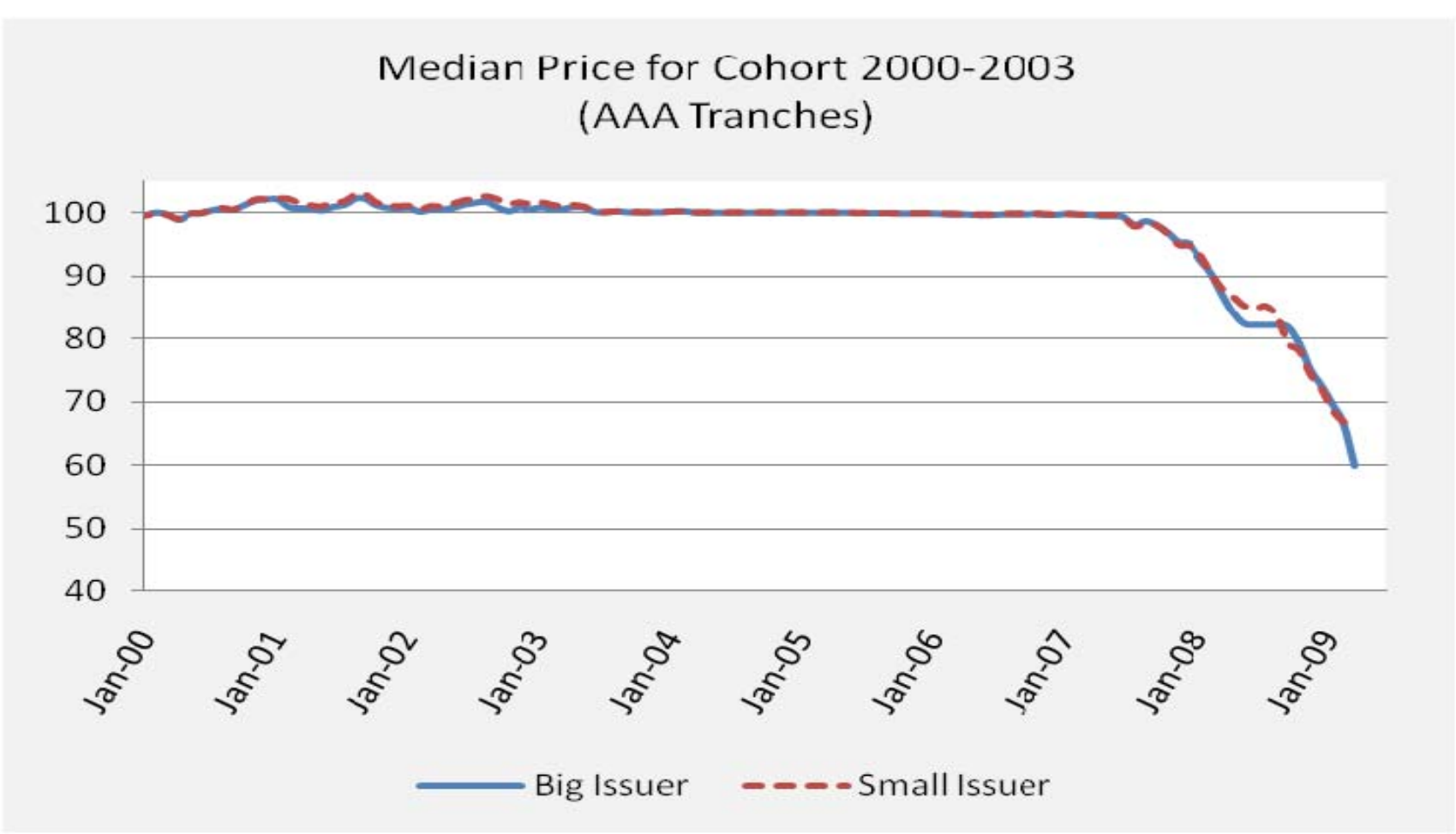

Figure 2, Panel A

\footnotetext{
${ }^{6} \mathrm{He}$, Qian, and Strahan (2010) find similar results in multivariate regressions controlling for the characteristics of the tranches and issuers. He et al (2010) also show that the market 'prices' the additional risk in large-issuer deals based on yields at issuance.
} 


\section{Median Price for Cohort 2004-2006 \\ (AAA Tranches)}

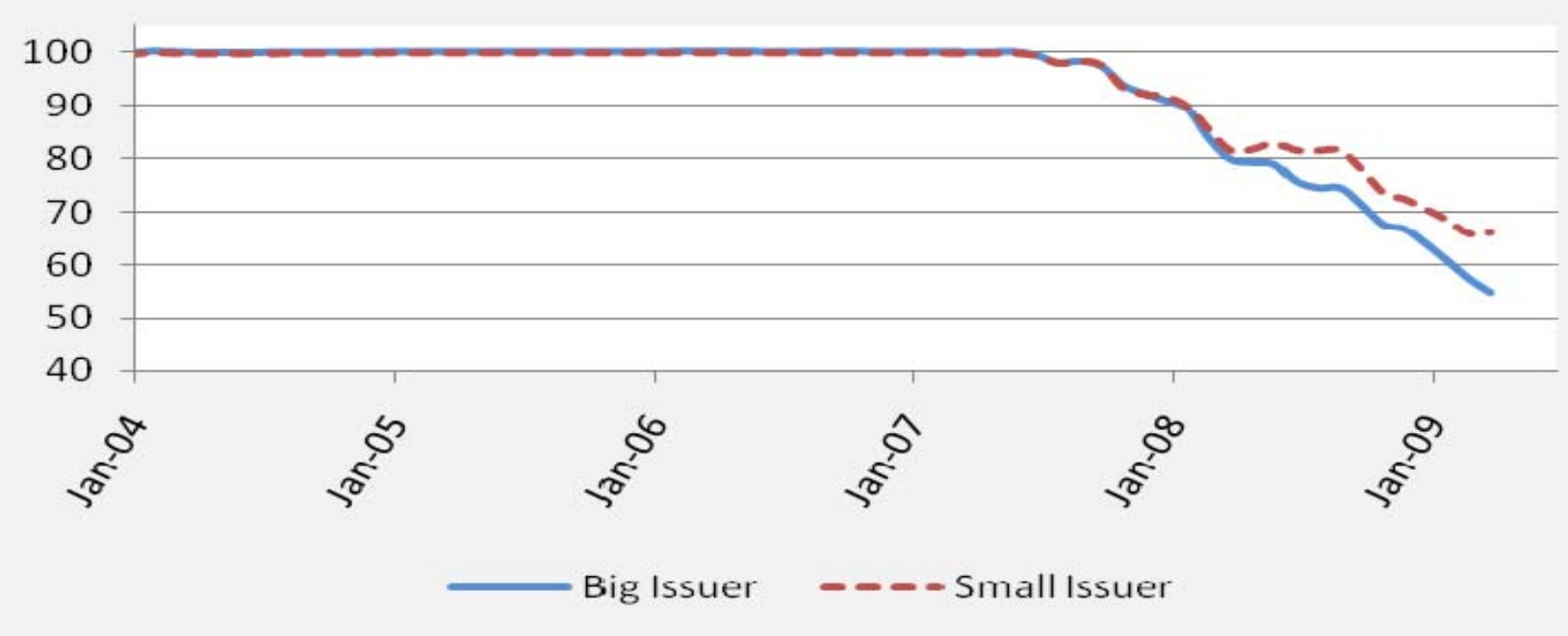

Figure 2, Panel B

Figure 2: Monthly Prices of Private Mortgage-Backed Securities

Panel A (Panel B) of Figure 2 shows the median monthly price change, relative to par (\$100) of privately-issued AAA-rated mortgage-backed securities, including all the tranches for which we can observe prices on Bloomberg originated between 2000 and 2003 (between 2004 and 2006). "Big issuer" means that the market share of the issuer falls into the top $10 \%$ of the market share distribution in that year; "Small issuer" refers to the rest of the sample. The price history starts from the month of origination until the security stops trading or April 2009 (whichever comes first).

\section{FINAL REMARKS}

Our paper tests whether conflicts of interest affected ratings in one of the largest and fastest growing credit markets. Most agree that rating agencies played an integral role in the rise and fall of housing and subprime lending. Our findings suggest that ratings mistakes were systematically correlated with issuer size and market conditions. All three major rating agencies were more optimistic for securities sold by large issuers during the boom years. A larger fraction of MBS deals sold by large issuers receive AAA ratings than deals sold by small issuers. Tranches sold by large issuers then experience larger price drops than those sold by smaller issuers when the 'housing bubble’ began to unravel. These structural and performance differences are concentrated among 
deals packaged and sold during the market boom years of 2004 through 2006 . We conclude that the conflict of interest problem of rating agencies likely played a significant role in the evolution of the MBS markets.

\section{REFERENCES}

1. Ashcraft, Adam, Paul Goldsmith-Pinkham and James Vickery, 2009. "MBS Ratings and the Mortgage Credit Boom,” working paper, Federal Reserve Bank of New York.

2. Bar-Isaac, Heski and Joel Shapiro, 2010. “Ratings Quality over the Business Cycle,” working paper, Oxford University.

3. Becker, Bo, and Todd Milbourn, 2009. "How did Increased Competition Affect Credit Ratings?” Journal of Financial Economics, forthcoming.

4. Benmelech, Efraim, and Jennifer Dlugosz, 2009a. “The Alchemy of CDO Credit Ratings,” Journal of Monetary Economics 56, 617-634.

5. Bolton, Patrick, Xavier Freixas, and Joel Shapiro, 2009. “The Credit Ratings Game,” working paper, Columbia University.

6. Coval, Joshua, Jakub Jurek, and Erik Stafford, 2009. “The Economics of Structured Finance,” Journal of Economic Perspectives 23, 3-25.

7. Gorton, Gary and Andrew Metrick, 2010, “The Run on the Repo,” Journal of Financial Economics, forthcoming.

8. Griffin, John, and Dragan Tang, 2009. “Did Subjectivity Play a Role in CDO Credit Ratings? Working paper, University of Texas, Austin.

9. He, Jie, Jun Qian and Philip E. Strahan, 2010. “Are Issuer Size and Ratings Shopping 'Priced' in the Mortgage-backed Securities Market?” working paper, Boston College.

10. Mian A. and A. Sufi, 2008, “The consequences of mortgage credit expansion: Evidence from the 2007 mortgage crisis,” Quarterly Journal of Economics 124(4), 1449-96. 